\title{
First European Symposium on Marine Biology (Helgoland, 1966): opening address
}

\author{
OTto KinNe \\ Biologische Anstalt Helgoland, Zentrale, Hamburg 50
}

\author{
Meine Damen und Herren! \\ Mesdames et Messieurs! \\ Ladies and Gentlemen!
}

When I sat down to think about this address, a major difficulty presented itself: Simultaneous translation service will not be available until the formal beginning of the lectures tomorrow; so - welche Sprache - quelle langue - which language - should I use? The difficulty was considerably reduced by the fact that I can offer only two languages: Deutsch and English. Je regrette beaucoup, je ne parle pas français. After some more thinking I came up with a surprisingly simple answer to this dilemma. I shall neither talk "auf Deutsch“ nor in English; I decided to use a third, nonEuropean language, and do hope you will approve of my choice: I decided to address you in Canadian.

Dear Colleagues and Friends:

This moment is the culmination of a development which took place over a period of many years. Time and again marine biologists have stressed the need for more intensive co-operation and for closer scientific and personal contacts. The field of Marine Biology draws upon a multitude of sources; it is interdisciplinary as well as international in character; there is urgent need for increased integration in order to counterbalance specialization as well as intellectual and geographical isolation.

It is with the greatest pleasure that I welcome you here on Helgoland. Thank you very much indeed for accepting our invitation. My colleagues from the Biologische Anstalt Helgoland and I are very pleased to note that some 230 scientists from 24 different nations have come here in order to present papers and to discuss problems of mutual interest. It is our sincere hope that this symposium will stand up to your expectations and that it will initiate a long, fruitful series of similar meetings. The announcement of the First European Symposium on Marine Biology has met with a world-wide echo of warm sympathy. More than 100 letters and telegrams have reached us from all over the world. They were sent by friends and colleagues who were because of financial problems or previous commitments - unable to attend personally. 
I am to convey to you their greetings and best wishes for a successful and rewarding symposium. In addition to the 24 countries represented here, well-wishing addresses came from Australia, Bulgaria, Chile, Hungary, Iran, Israel, Japan, and Poland.

I have the honour of welcoming especially our guests from foreign countries on behalf of Herr Bundesernährungsminister HöcHerL, and the members of his Ministry, particularly Dr. Meseck, Dr. Mengel and Herr MöckLInghoff, who wish you a pleasant stay in the Federal Republic of Germany. Greetings are sent by my predecessor, Professor A. BückmanN, who was in charge of the Biologische Anstalt Helgoland from 1953 to 1960 - because of $i l l$ health he cannot, unfortunately, attend this meeting -, and by the municipality of Helgoland and its mayor, Herr RiскмеRs.

The First European Symposium on Marine Biology was made possible through financial support from the Bundesernährungsministerium, Bonn. The Ministry has favoured our endeavours with much understanding and good will. In addition, our friends on Helgoland have lent support to our plans right from the beginning. As a warm gesture of welcome and respect, they have raised the flags of all nations represented; they have put part of their beautiful school at our disposal, arranged a reception for symposium participants, made the heated sea-water swimming pool available for us on Thursday evening, and, finally, they have organized a "Lampion" boat excursion for us. We are grateful for all this support. Last, but not least, I would like to thank the scientists, technicians and administrative personnel of the Biologische Anstalt Helgoland for their enthusiastic help in preparing this meeting; special thanks are expressed to Drs. P. Kornmann, W. Gunkel, and H. Bohling, who helped with the local organization, and to the members of the "Symposium Office", especially Miss F. W. Crouse, Miss L. Musgrove, Frau G. Wurl, Fräulein U. Bosse, and Herr J. Marschall.

Please let me add a few words about the history, scope and aims of the series of European Marine Biology Symposia, which this meeting is meant to initiate. The history goes back to 1960 when a series of German marine biological symposia was initiated by the Biologische Anstalt Helgoland; later on, these symposia were also sponsored by the Institut für Meereskunde, Kiel, and the Institut für Meeresforschung, Bremerhaven. It soon became apparent that these symposia attracted many colleagues from other European countries and from abroad. The conviction grew that international participation should be encouraged. Thus the fifth symposium of this series was organized by the Marine Botanical Institute in Göteborg, Sweden. It was at the symposia in Hamburg (1963), Göteborg (1964), and Bremerhaven (1965), that the need for a new series of European Symposia on Marine Biology became apparent. In Göteborg I was asked to find out the opinions of European marine biologists, including those who had not been able to attend either of these meetings. Accordingly, in November 1965 some 200 questionnaires were sent out containing three basic questions. The three questions asked and the answers received in 158 returns were as follows: 
Questions

(1) Do you feel there is a need for an annual or bi-annual European symposium in the field of marine biology?

(2) Would such a symposium suffice to provide a platform for the exchange of ideas and for personal contacts among European colleagues, or do you feel there is need for the founding of a "European Association of Marine Biologists" (or whatever such an association should be called)?

(3) If such an association were to be founded, do you feel that it should be a subdivision of international bodies already existing?
Responses

Answers in percentages

(rounded-off figures)

Yes

$98 \%$

No $2 \%$

It seems that the general consensus of opinion obtained can best be expressed in the following five points:

(a) The strong international and interdisciplinary components in the field of Marine Biology demand adequate contacts between countries and individuals.

(b) While our colleagues primarily concerned with fisheries research and quantitative planktology have for many years enjoyed the advantages gained from communicating through international channels, marine biologists - that is, those colleagues who are working at the numerous Marine Stations, University Departments and related institutions largely concerned with basic research on life in oceans and coastal waters have, in contrast, been rather isolated.

(c) An annual or bi-annual series of European Symposia on Marine Biology is urgently needed to fill this gap. These symposia should be sponsored by marine biological institutions in Europe; they should be open also to colleagues from outside this area.

(d) An administrative body may prove to be necessary in order to provide (a) for continuity of the new symposium series, (b) for consideration of applications by institutions willing to act as sponsors, (c) for obtaining financial support, and (d) for establishing close contacts with relevant regional and international organizations. These matters should be discussed further during the First European Symposium on Marine Biology on Helgoland.

(e) Details concerning symposium programmes and organizational aspects should be left largely to the inviting institution. In order to restrict the number of participants so as to allow for an efficient exchange of ideas, for working sessions and for discussions, each symposium should have one or more quite specific topics.

I suggest that a committee be formed here during this symposium consisting of representatives from all European nations. The committee should meet during one of the next evenings and discuss the various points mentioned in greater depth. It is hoped that the committee will take on the responsibility of deciding on appropriate 
steps so as to ensure the continuity of the newly created series of European Marine Biology Symposia.

In the last part of this address, I would like to add a few remarks about the Biologische Anstalt Helgoland. Our institution was founded in 1892. Its present activities are devoted to (1) basic research in all fields of Marine Biology; (2) advancement of knowledge on the life in the sea by offering (a) research space to visiting scientists, (b) course rooms, material and advice to courses organized by universities, (c) conducting our own courses on marine biological subjects, (d) supplying scientific institutions with living or fixed marine material, and (e) maintaining a public aquarium also used for teaching and research.

The Biologische Anstalt Helgoland consists of three groups of facilities: Central Laboratory (Zentrale), Marine Station (Meeresstation) and Littoral $\mathrm{S} \mathrm{t}$ a $\mathrm{t}$ i o $\mathrm{n}$ (Litoralstation), all located in strategically well-chosen localities.

The Central Laboratory is located in Hamburg, one of the largest cities in Europe, having a modern airport, a big university and a multitude of other scientific and cultural institutions. The main building houses a number of laboratories and staff offices, a circulating sea water system, special experimental rooms and a small library as well as the Director's permanent quarters and the administration.

The $\mathrm{M}$ a rine Station on Helgoland has some 26 laboratories, 15 of which are available for visiting scientists, a large running sea water system, a public aquarium and a moderate library (which is presently being enlarged); among the various special rooms are 7 temperature-controlled rooms, 2 course rooms and several sorting and maintenance rooms for animals and plants. The laboratories for visiting scientists are equipped especially for ecological, physiological, electro-physiological, radio-biological and biochemical work. In addition to the main building, a harbour laboratory, a guest house with 25 rooms, and 9 houses for permanent staff members, belong to the Marine Station on Helgoland. Construction of a dormitory for students, university teachers and visiting scientists is now underway. It will offer place for 50 persons and is expected to be opened in spring 1968. A new building for experimental ecology is presently being planned. Around the island of Helgoland exists the richest marine fauna and flora within the boundaries of Germany; the primary substrates are rock (red sandstone), gravel and sand.

The Lit $\mathrm{t}$ oral $\mathrm{Stat}$ io $\mathrm{n}$ in List on the island of Sylt is housed in an old harbour building. It comprises facilities for 2 scientists, 2 course rooms and a small circulating sea water system. In the near future, a new, additional building will be erected, and more facilities will be made available for visiting scientists. The area around List is characterized by dunes, sandy beaches and extensive mud flat areas. Thus the Littoral Station in List offers access to quite different habitats and working conditions than does the Marine Station on Helgoland. Fortunately, it has been possible to make a new $34,000 \mathrm{~m}^{2}$ area available for future extensions of the Littoral Station. This new area is located near the old Station and includes a dune and sand region directly on the shore.

The staff of the Biologische Anstalt Helgoland consists of about 110 persons, 25 of whom are scientists. In addition there are 9 "Doktoranden" (Ph. D. students). The scientific staff is subdivided into 7 different divisions: Zoology, Physiology, 
Botany, Microbiology, Planktology, Ichthyology and Radiation Biology. Our institution maintains a $24 \mathrm{~m}$ long research vessel, the "Uthörn", and several smaller motor boats; a new some $38 \mathrm{~m}$ long research vessel is under construction and will be ready for use in early spring 1968.

Should any of you be interested in working on Helgoland or on Sylt, you will be most welcome to do so. Our facilities are available for colleagues from Germany as well as from any other country. Further details concerning our institution and its activities may be found in our annual reports.

The First European Symposium on Marine Biology will deal with three topics:

(1) Experimental ecology - its significance as a marine biological tool

(2) Subtidal ecology - particularly as studied by diving techniques

(3) The food web in the sea.

It is my sincere hope that the papers and discussions delivered here will advance our knowledge about life in oceans and coastal waters and that each participant will be enriched and will enjoy giving and receiving. opened.

With this hope I declare the First European Symposium on Marine Biology 